\title{
PERSEPSI CIVITAS AKADEMIKA UIN MALANG TERHADAP PENGARUSUTAMAAN GENDER
}

\author{
M. Mahpur, M.Si \\ Dosen Fakultas Psikologi UIN Malang
}

\begin{abstract}
ABSTRAK
This research is intended to describe the perception of UIN academics on gender mainstreaming issue and to map the argument on the need of gender mainstreaming implementation which includes gender strategy and gender practice at this academic institution. Using descriptive quantitative methode, the data gathered in the form of openmind-system questionnaires distributing to the Deans, vice deans, and head of several units.

The result of research reveals that either men or women at UIN Malang tend to refuse the implementation of gender mainstreaming (men=44.67\% and women=25.33\%). Only 35\% of total amount of respondent agree to implement gender mainstreming (men=15 dan women=20\%). Meanwhile, the respons toward the implementation is that word "gender"in vision and mission of this institution is not necessary to be stated explicitely. The important point of the issue is the practice of gender quality should be proportional andprofesional. Then, this is a responsibility of centre of gender studies to socialize gender issues and gender equality if there is a need to evaluate gender equality-based policies.
\end{abstract}

\section{A. Pendahuluan}

Implementasi keadilan dan kesetaraan gender dalam pembangunan menjadi salah satu prioritas di Indonesia. Kebijakan yang terkait dengan pengarusutamaan gender telah melandasi berjalannya program pembangunan untuk menciptakan kesetaraan dan keadilan gender baik di lingkup instansi, lembaga publik atau berbagai organ social kemasyarakatan. Kantor kementerian Pemberdayaan Perempuan sesuai dengan platform GBHN (1999-2004) menyebutkan agenda pemberdayaan perempuan difokuskan pada keadilan dan kesetaraan gender di segala kehidupan berkeluarga, bermasyarakat, berbangsa dan bernegara ${ }^{1}$.

\footnotetext{
${ }^{1}$ Irwan, Z.D. 2001. Pemberdayaan Perempuan Menuju Keadilan dan Kesetaraan Gender. Perspektif.Edisi II/2001. hal.2-4.
} 
Pemerintah juga telah mengambil langkah bagi eliminasi diskriminasi terhadap perempuan melalui ratifikasi dan konvensi CEDAW (Convention on the Elimination of All Forms of Discrimination Againts Women) di tahun 1984. konvensi ini sebagai bentuk affirmative action yang memerintahkan negara agar segera melakukan temporary special measures sebagai jalan mengatasi atau mencegah adanya de facto discrimination.

Di bidang pendidikan, platform mengenalkan sejumlah pendekatan dalam mencapai tujuan pendidikan pun perlu memperhatikan formulasi dan sinergi dalam rangka menimbang usaha munculnya kesetaraan dan keadilan gender dari berbagai segmen yang menunjang kelengkapan institusi pendidikan. Institusi pendidikan masih dianggap netral, yang berarti tidak membatasi bagi potensi laki-laki dan perempuan sebagai pusat pembuatan kebijakan dan perlunya pengarusutamaan gender dalam berbagai kondisi. Netralisasi ini berarti bukan mencerminkan bahwa tiadanya diskriminasi dan pembedaan terhadap kapasitas peran gender di dalam pendidikan, akan tetapi netralitas dipandang sebagai ketiadaannya responsibilitas dalam pendidikan padahal berbagai peristiwa dan fakta yang menunjukkan rendahnya akses dan kesempatan perempuan untuk bersama-sama mencapai tujuan pembangunan berangkat dari persoalan pendidikan yang mengabaikan dimensi pencapai target pendidikan yang kurang memperhatikan kesetaraan dan keadilan gender atau disebut masih terperangkap ketidakadilan gender dalam berbagai struktur kelembagaan, kebijakan, atau pengembangan kurikulum dalam pendidikan.

Perguruan tinggi Islam merupakan bagian dari agen perubahan social. Oleh karena itu diharapkan bahwa disamping menjalankan fungsinya dalam bidang pengembangan dan penerapan ilmu pengetahuan, perguruan tinggi Islam diharapkan mampu melaksanakan dekonstruksi nilai social budaya yang terkandung di dalamnya, diantaranya nilai-nilai relasi gender. Oleh karena itu, profil atau peta kondisi obyektif relasi gender yang ada di lingkungan perguruan tinggi Islam merupakan acuan rancang bangun instrument pembangunan dan mengevaluasi tingkat perkembangan partisipasi, dan kontribusi seluruh komponen sivitas akademika di lembaga pendidikan sebagai salah satu komponen penting dalam proses terciptanya pengarusutamaan gender.

Adapun kasus Universitas Islam Negeri (UIN) Malang, selama ini, Pusat Studi Gender belum mendapatkan sejumlah asupan data yang menggali kondisi riil isu-isu yang terkait dengan kesetaraan dan keadilan gender di semua elemen kelembagaan, jabatan, pembelajaran dan 
komponen lain khususnya persepsi pejabat di tingkat fakultas mengenai muatan pengarusutamaan gender.

Bertolak dari latar belakang dia atas, maka permasalahan yang dapat dirumuskan dalam penelitian ini adalah sebagai berikut?; 1) bagaimana realitas persepsi sivitas akademika UIN mengenai pengarusutamaan gender?; 2) apa argumentasi yang merespon pemetaan masalah urgens-tidaknya pengarusutamaan gender oleh pejabat?

\section{B. Kajian Pustaka}

\section{Konsep dan Prinsip Umum pengarusutamaan gender}

Sampai saat ini, konsep pengarusutamaan gender di kalangan luas belum dipahami secara proporsional. Tidak hanya masyarakat awam yang kesulitan memahami pengarusutamaan gender, tetapi juga kelompok yang cukup terdidik. Bahkan gagasan strategis ini sering dicemaskan dan dicurigai banyak pihak, terutama kelompok yang kuat mempertahankan status quo.

Sebelum jauh menakar signifikansi gender dalam pendidikan tinggi berikut akan diuraikan beberapa komponen yang menjelaskan secara terminologis apa yang dimaksud dengan pengarusutamaan gender atau dalam etimologi aslinya berasaldari gender mainstreaming. Penerjemahan pengarusutamaan gender dan biasa disingkat dengan PUG merupakan kata yang sudah umum menjadi deskripsi mengenai affirmative action pelaksanaan guna mewujudkan kesetaraan dan keadilan gender.

Gender Mainstreaming adalah integrasi kesamaan gender secara sistemik ke dalam seluruh sistem dan struktur, termasuk kebijakan, program, proses dan proyek, budaya, organisasi atau sebuah agenda pandangan dan tindakan ${ }^{2}$ yang memprioritaskan kesamaan gender.

Sedangkan kelompok spesialis mainstreaming di Dewan Eropa, mendefinisikan pengarusutamaan gender adalah reorganisasi, peningkatan, pengembangan dan evaluasi proses kebijakan, sehingga perspektif kesetaraan gender tergabung ke dalam seluruh kebijakan pada setiap level dan tingkatan, dengan pelaku yang secara normal ikut terlibat di dalam pembuatan kebijakan. $^{3}$

\footnotetext{
${ }^{2}$ European Women and Sport, 2002. A New Strategy : Gender Mainstreaming, Paper presented by Teresa Rees at the $5^{\text {th }}$ European Women and Sport Conference in Berlin, April $18^{\text {th }}-21^{\text {st }} 2002$ Hotel Crowne Plaza, Berlin ${ }^{3}$ Dr. Peter Doge. 2002. Theoretical Implications of Gender Mainstreaming. Overhead Slides. Tidak diterbitkan. www.IAIZ .de. Institut fur anwendungsorientierte, Innovations und Zukunftsforschung e.V.
} 
Sementara The ECOSCO (Economic and Social Council) menyetujui definisi tersebut sebagai kesimpulan (1997/2) bahwa gender mainstreaming merupakan proses yang mengukur implikasi-implikasi laki-laki dan perempuan dari berbagai tindakan yang terencana, inklusi pada wilayah perundang-undangan, kebijakan dan beragam program kedalam seluruh area dan tingkatan.

Menurut Doge ${ }^{4}$ gender mainstreaming berfokus pada beberapa pokok gagasan yang mencakup:

a) Memandang kesetaraan gender sebagai tugas lintas sektoral

b) Ambil bagian ke dalam sejumlah hubungan antara perempuan dan laki-laki

c) Tujuannya lebih pada perubahan struktur organisasi

d) Mempertimbangkan kebijakan yang tidak netral gender

Oleh karena itu ada dua elemen strategis bagi pengarusutamaan gender yaitu:

a) Elemen pertama disebutnya sebagai kesetaraan (equality), yakni sesuatu hak-hak, tanggungjawab atau peluang/kesempatan yang sama bagi laki-laki dan perempuan dari seluruh komponen ruang social.

b) Elemen kedua adalah keadilan (equivalence), yakni kesetaraan model hidup, keterampilan dan aktifitas bagi laki-laki dan perempuan. ${ }^{5}$

Pengarusutamaan gender adalah gerakan dinamis yang bermuatan anasir cultural, social dan politik. Ia melibatkan dan meniscayakan perubahan relasi gender, dari model hubungan atasbawah, paternalistic ke model relasi kemitraan dan kesetaraan. Semuanya pada intinya harus bermuara pada kegiatan untuk mencapai keseimbangan dan kemitraan kekuasaan (power), dan tanggung jawab mutual yang menguntungkan kedua belah pihak (laki-laki dan perempuan).

Pengarusutamaan gender mengharuskan perwujudan proyek, program dn beragam kebijakan untuk mempromosikan, mendorong dan mendukung perubahan gender laki-laki dan perempuan, sikap dan prilaku, yaitu perubahan yang lebih menyuarakan penggilan keadilan gender baik di lingkup domestic ataupun publik.

Dengan demikian, Pengarusutamaan gender menjadi tanggung jawab bersama, semua komponen kunci pembuat kebijakan, baik di level perencanaan, pembuatan sampai ke tingkat

\footnotetext{
${ }^{4}$ Ibid.,

${ }^{5}$ Ibid.,
} 
penegakan kebijakan tersebut. Negara bersama rakyat, baik kolektif maupun individual dituntut turut harus bahu-membahu berpartisipasi untuk program ini.

Adapun prinsip-prinsip yang digunakan dalam gender mainstreaming dapat dibagi menjadi tiga, yaitu: ${ }^{6}$

\section{a. Menghargai individu sebagai sosok yang utuh}

Konsep pertama ini meninjau bahwa ada tanggangan yang melihat kalau laki-laki sebagai kepala dalam sebuah organisasi maka perempuan menjadi bagian dari pekerjaan itu sendiri dalam situasi yang marjinal. Pada pokok prinsip pertama ini biasanya akses perempuan disebabkan sebagai belas kasian dan memiliki posisi kedua (the second position) dalam perlakuan struktur organisasi. Ia terkadang menjadi pekerja yang memfasilitasi atau terkait dengan alas an-alasan emosional bahwa jabatan ini sepantasnya dijabat oleh perempuan. Jabatan dan kebutuhan yang disebabkan oleh alas an politik psikis murni dan bukan didasari oleh kebutuhan riil akan profesi tertentu dalam sebuah organisasi.

Dalam pada itu di dalam setiap sistem organisasi penggajian, posisi, peluang, perlakuan, signifikansi, profesi didasarkan pada pandangan yang utuh tentang pribadi dan tidak diibaratkan Karena alasan yang mendasar mengenai alasan penjeniskelaminan. Oleh karena itu pilihan terhadap sebuah posisidalam organisasi tidak dinyatakan berdasarkan alas an tipikal seksnya.

\section{b. Demokrasi}

Dalam aspek ini pengarusutamaan gender mempertimbangkan sketsa demokrasi yang memperhitungkan signifikansi perundingan dan mendorong tumbuhnya partisipasi di dalam pembentukan, penyusunan, perncanaan dan pelayanan kebijakan.

Kebutuhan terhadap iklim demokrasi senjatanya memperhatikan alokasi sumber-sumber yang langka pada basis kebutuhan antara apa yang terekspresikan dan tidak diekspresikan, dimana keduanya lebih dari sekedar pola-pola histori. Untuk menunjang demokrasi berdasar pada pengarusutamaan gender kinerja organisasi harus menciptakan budaya dan organisasi yang mana laki-laki dan perempuan merasa nyaman dalam mengekspresikan pandangan dan

\footnotetext{
${ }^{6}$ Hazel Reeves and Sally Baden. 2000. Gender and Development: Frequently Asked Questions. Prepared for the Department for International Development (DFID) for its gender mainstreaming intranet resource. Report No 57. BRIDGE (development gender) Institute of Development Studies University of Sussex.
} 
kebutuhan-kebutuhannya. Jadi prinsip demokrasi secara mendasar ingin mewujudkan keterlibatan secara penuh dalam partisipasi demokrasi.

\section{c. Fairness, justiceand equity}

Keadilan sosial merupakan jantungnya pengarusutamaan gender. Keadilan sosial menjadi prinsip yang penting dalam pengarusutamaan gender agar mendorong kesehatan di dalam inklusi sosial. Proses ini meliputi alokasi sumber daya manusia seperti pengembangan pengukuran yang progresif, realokasi perencanaan sumber daya yang sesuai dengan kebutuhan anggota.

\section{Urgensi Pengarusutamaan gender}

Untuk mewujudkan relasi gender yang berkeadilan sedapat mungkin menghilangkan kesenjangan hubungan dan pembagian kerja antara laki-laki dan perempuan dalam berbagai bidang kehidupan dengan memperhatikan kodrat, harkat dan martabatnya. Lebih lanjut, diketahui pula latar belakang kondisi dan masalah yang menjadi penyebabnya dengan menggunakan teknik analisis gender.

Teknik analisis gender dikembangkan di Indonesia dimaksudkan untuk mengetahui kesenjangan serta ketimpangan gender dalam proses pembangunan. Dengan mengetahui kesenjangan dan ketimpangan serta latar belakang munculnya dapat dijadikan dasar arah pemberdayaan perempuan agar kesetaraan gender terwujud dalam kehidupan sehari-hari. Dengan cara pandang yang demikian, pemberdayaan perempuan tidak dilandasi oleh sikap atau keinginan untuk menciptakan persaingan yang tidak sehat, tetapi kompetisi yang berkeadilan yang diharapkan karena pada hakikatnya antara laki-laki dan perempuan laki-laki dan perempuan potensial untuk sama-sama berusaha dan berprestasi baik mandiri maupun bekerja sama lintas gender.

Untuk mewujudkan hal itu maka gagasan pokok gerakan gender perlu melakukan tindakan yang biasa disebut dengan affirmative action. Affirmative action adalah suatu tindakan khusus

yang dilakukan untuk mendorong upaya kesetaraan gender menuju keadilan gender dengan lebih memperhatikan ketidakadilan melalui jalur struktural seperti menetapkan Undang-undang, Peraturan Pemerintah, Instruksi Presiden, Peraturan Daerah, Anggaran Dasar/ Anggaran Rumah 
Tangga Organisasi atau policy dari pengambil kebijakan atau sejenisnya. Dalam hal ini Negara berperan dalam upaya terwujudnya keadilan gender melalui tindakan affirmative action ${ }^{7}$. Misalnya memberikan cuti haid, hamil, melahirkan untuk melaksanakan peran reproduksi perempuan sebagai amanat Tuhan yang harus dihormati oleh setiap manusia. Penyediaan penitipan anak agar ibu yang bekerja dapat memberikan ASI pada jam-jam tertentu.menetapkan kuota bagi perempuan dalam partisipasi politik, memberikan beasiswa pada anak perempuan atau laki-laki putus sekolah karena membantu bekerja mencari nafkah keluarga.

Afirmative action juga ditempuh melalui jalur cultural, misalnya melakukan perubahan pola pikir yang dimulai dari kajian akademis dengan memperhatikan keberpihakan terhadap pihak jenis kelamin tertentu yang sedang mengalami ketertinggalan dan diskriminasi dengan menggunakan analisis gender. Hasil kajian tersebut kemudian diimplementasikan dalam kehidupan agar dapat merubah persepsi dan prilaku masyarakat menuju keadilan gender, bahwa laki-laki dan perempuan adalah setara. Untuk mengetahui apakah laki-laki dan perempuan telah setara dan berkeadilan, dapat dilihat pada :

1. Seberapa besar akses dan partisipasi atau keterlibatan perempuan terhadap peran sosial dalam kehidupan baik dalam keluarga masyarakat, dan dalam pembangunan.

2. Seberapa besar control serta penguasaan perempuan dalam berbagai sumber daya manusia maupun sumber daya alam dan peran pengambilan keputusan dan lain sebagainya.

3. Seberapa besar manfaat yang diperoleh perempuan dari hasil pelaksanaan berbagai baik sebagai pelaku maupun sebagai pemanfaat dan penikmat hasilnya.

Sosialisasi gender melalui jalur struktural yang dipandang lebih efektif adalah melalui pendidikan, yakni dengan menintegrasikan ke dalam manajemen pendidikan responsife gender, pembelajaran inklusif gender dan didukung pula oleh kebijakan pendidikan yang responsife gender. Pembelajaran inklusif gender adalah pembelajaran dengan mengintegrasikan gender ke dalam materi/bahan ajar yang berkesetaraan dan keadilan gender dengan menggunakan metode pembelajaran yang menghindari terjadi diskriminasi gender. Demikian pula dengan melalui strategi yang sama juga berlaku pada materi dan metode penyampaian pesan-pesan keagamaan inklusif gender yang dilakukan oleh pemuka agama. Hal ini penting artinya dalam mewujudkan kesetaraan dan keadilan gender melalui jalur kultural yang dinilai lambat tapi terintegrasi langsung dalam kehidupan.

\footnotetext{
7 Peggy Antrobus, The Global women Movement (Bangladesh: The University Press, 2004) hal.150
} 
Sementara wilayah pendidikan tinggi juga perlu melaksanakan formulasi PUG agar terjadi konsistensi tujuan, manajemen yang bisa efektif terhadap kinerja dan produktifitas antara lakilaki dan perempuan secara seimbang tanpa mengganggu dinamika internal dan eksternal pada pribadi seseorang.

Jika gender sebagai isu bagi setiap orang maka kita perlu menemukan jalan bekerja yang konstruktif antara laki-laki dan perempuan untuk membangun kepercayaan bagi sebuah tindakan yang berbeda-beda (if gender is to be everybody's issue, then we need to find constructive ways of working with men as well as with women to build the confidence to do things differently) ${ }^{8}$.

Oleh karena itu pengarusutamaan gender di dalam organisasi menurut Doge dipetakan dalam dua tujuan untuk :

a) Mengadaptasi struktur organisasi sebagai dasar bagi tercapainya kesetaraan (equality). Artinya merubah struktur yang telah mapan agar signifikan dengan kebutuhan pengarusutamaan gender.

b) Struktur organisasi yang adaptif terhadap yang mencerminkan adanya keragaman (diversity) posisi dari setiap elemen-elemen yang mendukung berjalannya fungsi dan kinerja organisasi. Fokusnya lebih pada fleksibilitas organisasi yang mendasari kinerjanya pada asumsi pengarusutamaan gender dan lebih inkusif terhadap pokok-pokok persoalan yang langsung mengakomodasi berbagai kepentingan yang bermuara pada terwujudkan kesetaraan dan keadilan gender.

Ketika pendidikan tinggi dilihatb dari perspektif yang lebih luas dalam konteks pengarusutamaan gender maka konsep Doge ${ }^{9}$ menjadi satu dasar yang bisa menunjukkan atau bisa memetakan bagi proses adaptasi organisasi pendidikan tinggi. Penelitian ini mencoba mengakumulasi kebutuhan-kebutuhan awal terkait dengan pengarusutamaan gender di pendidikan tinggi, khususnya dalam pendidikan tinggi Islam yang terkait lebih dulu dengan melihat persepsi pejabat sebagai penjajakan awal.

Basis persepsi ini didasari oleh asumsi bahwa pengarusutamaan gender di pendidikan tinggi Islam belum sepenuhnya ada dan apalagi bisa diterima dengan wawasan dan sikap demokrati. Persoalan ini menjadi sumber inspirasi untuk melakukan prosesi masalah tentang pandangan pejabat di lingkungan pendidikan tinggi Islam yang masih jarang dilakukan selain yang selama

\footnotetext{
${ }^{8}$ Hazel Reeves and Sally Baden.2000. Gender and Development: Frequently Asked Questions. Prepared for the Department. Dikutip dari pemikiran Andrea Cornwall, 1997:12

${ }^{9}$ Doge.2002. Theoretical Implications of Gender Mainstreaming.
} 
ini sudah dilakukan oleh Universitas Islam Negeri Yogyakarta dan Syarif Hidayatullah Jakarta tentang baseline gender di masing-masing institusi. Hal ini artinya bisa dipahami kalau pengarusutamaan gender lebih dahulu mengenali sumber masalahnya dari pada langsung mempraktikkan sebagai strategi kebijakan.

\section{Metode Penelitian}

\section{Fokus Penelitian}

Fokus penelitian ini mencakup beberapa tema khusus yang mempresentasikan tanggapan aspek-aspek yang ingin dikembangkan dalam pengarusutamaan gender. Klasifikasi fokus masalah ini, peneliti pertimbangkan sebagai bahan dasar untuk mengetahui realitas kognitif subyek penelitian yang terdiri dari pejabat structural tentang alur agreement-nya dan reaksi terhadap unsur-unsur yang kami tonjolkan sebagai aspek yang perlu dalam pengarusutamaan gender. Adapun fokusnya antara lain:

\section{a. Kebutuhan gender strategis}

Yakni kebutuhan kesetaraan dan keadilan gender yang didasarkan pada substansi masalah yang dihimpun dalam aspek filosofis dan fungsional terkait dengan posisi dan keberadaan laki-laki dan perempuan dalam setiap acuan kebijakan yang ada di masing-masing fakultas atau unit tertentu. Kebutuhan gender strategis dibagi ke dalam lima sub fokus (faktor) yang secara spesifik mewakili kebutuhan gender strategis yaitu;
a. Wilayah visi dan misi
b. Perangkat lunak (software) kebijakan
c. Instrumen kebijakan
d. Penataan sistem organisasi
e. Penataan Sumber Daya Manusia

\section{b. Kebutuhan gender praktis}

Yaitu kebutuhan langsung bisa dipenuhi secara operasional dan teknis terkait dengan implementasi pengarusutamaan gender di setiap kebijakan masing-masing institusi. Kebutuhan gender praktis yang langsung bisa dipenuhi dapat di fokuskan pada factor yaitu;

1. Eksplitasi tata kebijakan fakultas berkeadilan dan berkesetaraan gender 
2. Perangkat pendukung tugas perempuan

3. Peraga sensitive gender

4. Evaluasi Kebijakan

\section{Prosedur penelitian}

\section{a. Partisipan}

Dalam penelitian ini, yang menjadi subyek penelitian adalah pejabat dekanat terdiri dari Dekan, Pembantu Dekan I dan II, ditambah minor kepala jurusan dan program semua fakultas di Universitas Islam Negeri Malang. Sementara itu karena komposisi laki-laki dan perempuan dalam tatanan organisasi di setiap fakultas kurang merata dan pembagian porsi representasi laki-laki dan perempuan tidak berimbang maka peneliti melakukan pengembangan subyek pada tingkat unit-unit yang ada di Universitas Islam Negeri Malang. Karakteristik subyek penelitian ini kami sandarkan hanya pada jabatan inti di setiap organisasi fakultas. Hal ini karena penelitian ini ingin melihat aspek yang paling penting di rumpun pengambil kebijakan sebagai bahan awal untuk pengembangan analisis gender dan dengan demikian secara substansial wilayah pengambil kebijakan menjadi sesuatu yang sangat dikaji.

\begin{tabular}{|ccccc|}
\hline & \multicolumn{3}{c|}{ Jenis Kelamin } \\
\cline { 2 - 5 } Fakultas & Dekan & PD 1 & PD 2 & Kajur/kaprog \\
\hline Psikologi & Laki-laki & Perempuan & Laki-laki & - \\
Syariah & Laki-laki & Perempuan & Laki-laki & - \\
Tarbiyah & Laki-laki & Laki-laki & Laki-laki & - \\
Ekonomi & Laki-laki & Laki-laki & Laki-laki & - \\
Saintek & Laki-laki & Laki-laki & Perempuan & - \\
Humaniora & Laki-laki & Laki-laki & Perempuan & Perempuan \\
\hline
\end{tabular}

\section{b. Teknik pengumpulan data}

Data-data yang digunakan dalam penelitian ini ada dua jenis, yakni data persepsi yang menggambarkan agreement yang disusun sebagai stimulus mengelkuarkan pendapat subyek penelitian. Data tersebut menjadi gambaran yang telah diperoleh guna dijadikan pedoman untuk jenis data kedua. Data ini berupakuesioner dengan jawaban ya dan tidak. 
Pengumpulan data kedua dengan memberikan komentar sebagai reaksi stimulant peneliti yang berisi pendapat secara singkat mengapa responden menjawab ya dan alasan apa responden menjawab tidak. Instrumen ini peneliti sebut sebagai kelompok kuesioner dengan open ended system.

Kuesioner tersebut disusun berdasarkan konstruksi kebutuhan gender strategis kebutuhan gender praktis. Kebutuhan gender strategis terdiri dari lima faktor yaitu wilayah visi dan misi, perangkat lunak (software) kebijakan, instrumen kebijakan, penataan sistem organisasi dan penataan Sumber Daya Manusia dengan jawaban ya dan tidak untuk respon agreementnya. Dan untuk memperoleh alasan tentang respon agreement-nyakuesione ditambah komentar yang bersifat open ended system yang menggambarkan argumentasi penerimaan dan penolakan stimulan yang disajikan peneliti.

Sementara itu untuk kebutuhan gender praktis disusun juga sesuai dengan kriteria tersebut. Kebutuhan gender praktis peneliti fokuskan pada hal-hal tertentu yakni;

1) eksplitasi tata kebijakan fakultas berkeadilan dan berkesetaraan gender,

2) perangkat pendukung tugas perempuan, 3) peraga sensitive gender, 4) evaluasi kebijakan dengan pernyataan agreement yang direspon dengan jawaban ya dan tidak kemudian diikuti reaksi jawaban dengan memberi ruang komentar untuk mengungkapkan alasan atas jawaban tersebut.

Perlu diketahui bahwa kuesioner dengan sistem respon terbuka dimaksudkan untuk membuka opini terkait pandangan tentang pengarusutamaan gender. Dengan demikian peneliti tidak akan memutuskan adanya unsur-unsur item yang disebutkan menjadi bagian item yang favourable atau tidak, karena peneliti hanya melihat deskripsi opini sebagai respon atau stimulus yang peneliti lontarkan kepada responden. Artinya peneliti mencoba mencari sharing gagasan terhadap implementasi pengarusutamaan gender sehingga analisisnya nanti merupakan sinergi pendapat peneliti tentang titik-titik yang siap dan tidak siap atau memang tidak perlu, akan tetapi pengarusutamaan gender bisa diterima. Oleh karena itu, cakupan alat pengumpul data ini akan menjadi bahan bagi pengarusutamaan gender yang didasari oleh kesiapan pengetahuan basis sasaran program pengarusutamaan gender dan menyesuaikan kebutuhan kognitif dan praktik terhadapnya. 


\section{c. Analisis Data}

Data yang didapatkan dari sumber data primer dan sekunder tersebut kemudian dianalisis diskriptif untuk jajak agreement-nya dan analisis isi (content analysis). Di antara syarat teknik analisis isi adalah terpenuhinya syarat obyektivitas, pendekatan sistematis (dengan menggunakan criteria tertentu sebagai dasarnya) dan generalisasi (yang memiliki sumbangan teoritik). ${ }^{10}$

Analisis data dalam penelitian ini dilakukan secara induktif, yaitu penulis berangkat dari fakta-fakta dan ketentuan-ketentuan yang bersifat khusus kemudian membuat generalisasi analisis sehingga dapat ditarik kesimpulan yang bersifat umum.

Kegiatan analisis data dalam penelitian ini menggunakan tiga tahapan, yaitu reduksi data, penyajian data, verifikasi dan penarikan kesimpulan. Dalam proses reduksi data, peneliti menganalisis bahan-bahan yang telah terkumpul, menyusunnya secara sistematis, dan menonjolkan pokok-pokok permasalahannya. Tahap berikutnya adalah penyajian data. Dalam tahap ini, peneliti menyajikan sekumpulan informasi yang tersusun yang memberi kemungkinan adanya penarikan kesimpulan dan pengambilan tindakan. Data yang telah dipolakan, difokuskan, dan disusun secara sistematis sesuai kategori tema yang telah disusun berdasarkan temuan peneliti.

\section{Hasil Penelitian}

\section{Persepsi Pejabat Dekanat Terhadap Pengarusutamaan Gender}

Permasalahan atau focus penelitian yang pertama adalah realitas persepsi para pejabat penting terutama yang ada di tingkat dekanat cukup bervariasi. Fokus ini dapat dilihat dari hasil rata-rata jawaban dari kuesioner yang menggambarkan bagaimana pendapat atau persepai setiap factor atau variable yang dikembangkan untuk mengetahui persepsi mereka. Gambaran global bahwa menurut kajian penelitian ini aspek yang urgen bagi pengembangan pengarusutamaan gender secara menyeluruh dibagi menjadi dua komponen penting yakni, aspek yang terkait dengan kebutuhan gender strategis yang bersifat substansial yang menunjukkan unsur pokok bagi pencapaian kesetaraan dan keadilan gender. Jika dilihat pada table dibawah ini ada respon yang memadahi terkait dengan elemen kunci dalam pengarusutamaan gender ini. Bahwa

\footnotetext{
${ }^{10}$ Noeng Muhadjir. Metode penelitian kualitatif. Yogyakarta: Rake sarasin, 2002, 68-69.
} 
kebutuhan strategis terutama kemungkinan dimasukkannya substansi pengarusutamaan gender dalam seluruh kebijakan fakultas ada bervariasi respon yang diberikan responden.

Secara keseluruhan jika melihat table di bawah persepsi pejabat laki-laki dan perempuan lebih cenderung secara porsentase rata-rata tidak menerima (laki-laki=44.67\% dan perempuan=25.33\%) pengarusutamaan gender lebih besar dibanding yang menerima (lakilaki $=15 \%$ dan perempuan=20\%) walau mereka juga terbuka soal-soal khusus. Artinya persentase tersebut menjadi peluang diterimanya pengarusutamaan genderdi tingkat fakultas.

Ketika peneliti berpendapat bahwa pengarusutamaan gender harus masuk ke dalam seluruh aspek strategis kebijakan, maka untuk bagian visi dan misi semua responden tidak setuju adanya pemunculan statemen kesetaraan gender inklusif di dalamnya.

Ketidaksetujuan responden terhadap statemen kesetaraan gender inklusif didalam visi misi UIN Malang menunjukkan bahwa gender sensitivity dari pejabat pembuat kebijakan di tingkat fakultas masih belum terbangun dengan maksimal yang dapat membantu terwujudnya kesetaraan gender di lingkungan UIN Malang. Tidak tercantumnya statement kesetaraan gender menunjukkan bahwa pengarusutamaan gender bukan agenda penting dari UIN malang

Table 4. Distribusi Respon Persepsi Subyek Terhadap PUG

\begin{tabular}{|l|r|r|r|r|}
\hline \multirow{2}{*}{ Factor/Variabel } & \multicolumn{3}{c|}{ Respon(n=14) } \\
\cline { 2 - 5 } & \multicolumn{2}{|c|}{ Laki(\%) } & \multicolumn{2}{c|}{ Prp (\%) } \\
\cline { 2 - 5 } & setuju & \multicolumn{1}{c|}{ tidak } & setuju & tidak \\
\hline Kebutuhan gender strategis & & & & \\
\hline Wilayah visi dan misi (netral gender) & 0 & 60.00 & 0 & 40.00 \\
\hline Perangkat lunak (software) kebijakan & 23.33 & 33.33 & 30 & 30 \\
\hline Instrumen kebijakan & 10 & 46.67 & 30 & 26.67 \\
\hline Penataan sistem organisasi & 0 & 50.00 & 15 & 20 \\
\hline Penataan SDM & 26.67 & 33.33 & 27 & 10 \\
\hline \multirow{2}{*}{ Rata-rata } & $\mathbf{1 5}$ & $\mathbf{4 4 . 6 7}$ & $\mathbf{2 0}$ & $\mathbf{2 5 . 3 3}$ \\
Kebutuhan gender praktis & & & & \\
\hline Eksplitasi tata kebijakan fakultas berKKG & 26.67 & 50.00 & 17 & 23.33 \\
\hline Perangkat pendukung tugas perempuan & 20 & 35.00 & 28 & 12.5 \\
\hline
\end{tabular}




\begin{tabular}{|c|c|c|c|c|}
\hline Peraga sensitive gender & 40 & 20.00 & 25 & 20 \\
\hline Evaluasi kebijakan & 30 & 30.00 & 20 & 20 \\
\hline Rata-rata & 29.17 & $\mathbf{3 3 . 7 5}$ & 22 & 18.958 \\
\hline
\end{tabular}

Bagi pejabat laki-laki mereka cenderung memiliki persepsi tidak setuju terhadap pengarusutamaan gender dalam bidang kebutuhan strategis gender dan kalau dilihat menjadi subyek yang domonan memberi respon. Mereka dalam persepsi ini mentolerir masuknya pengarusutamaan gender pada bidang perangkat lunak kebijakan atau softwarenya yang setuju sebesar $23.33 \%$, instrumen kebijakan sebesar $10 \%$ dan penataan sumberdaya manusia yang didasarkan oleh responsif gender sebesar $26.67 \%$. walaupun prosentase ini kecil, namun ada peluang bagi masuknya pengarusutamaan gender pada ketiga wilayah tersebut.

Sedangkan pengarusutamaan gender di tingkat praktis gender cukup memberikan angin segar. Artinya kebutuhan praktis lebih banyak direspon daripada kebutuhan strategis. Bagi kebutuhan praktis persepsi pejabat terhadap pengarusutamaan genderkecenderungan bisa diterima., yakni untuk laiki-laki setuju adanya pengarusutamaan gender di wilayah praktis sebesar $29.17 \%$ dan perempuan sebesar $22 \%$. Adapun peluang yang paling tinggi adalah peraga sensitif gender (laki-laki=40\%, perempuan 25\%) dan evaluasi kebijakan fifty-fifty (lakilaki $=30 \%$ dan perempuan $=20 \%$ ). untuk perangkat pendukung tugas perempuan, responden memiliki persepsi setuju sebesar $28 \%$ dan laki-laki hanya $20 \%$. Jika diartikan perngakat kebutuhan ini memang secara langsung terkait dengan pengalaman perempuan.

Selain itu prosentase yang tidak setuju adanya kesetaraan dan keadilan gender terkait dengan kebutuhan praktis gender yakni laki-laki sebesar $33.75 \%$ dan perempuan sebesar $18 \%$. Artinya bahwa ada hal-hal khusus yang memang tidak dianggap urgen untuk kepentingan pengarusutamaan gender. Ketidaksetujuan itu lebih terfokus pada eksplitasi tata kebijakan fakultas yang berkesetaraan dan keadilan gender,prosentase yang menolak cukup tinggi baik laki-laki (50\%) dan perempuan (23.33\%).

\section{Argumentasi Pemetaan Masalah Pengarusutamaan Gender}

berikut ini deskripsi analisis mengenai respon balik pendapat subyek tentang aspek apa saja yang dianggap urgen dan tidaknya dalam pengarusutamaan gender. Alasan ini dapat dipetakan ke dalam dua ranah utama kebutuhan pengarusutamaan gender yaitu kebutuhan 
strategis gender dan kebutuhan praktis gender. Di bawah ini dilakukan analisis dengan cara melakukan coding argumentasi terhadap pendapat subyek tentang stimulus yang diajukan peneliti agar subyek memberi tanggapan, sanggahan atau ide tentang kepentingan dan pengarusutamaan gender. Analisis ini dibagi menjadi dua matra besar yang digali berdasarkan indikator strategis gender dan praktis gender seperti tertera pada tabel berikut.

Tabel 5. Argumentasi Subyek Tentang Urgensu PUG

\begin{tabular}{|c|c|c|c|}
\hline \multirow{2}{*}{ No Item } & \multirow{2}{*}{$\begin{array}{c}\text { Faktor/variabel } \\
\text { Kebuthan strategis } \\
\text { Gender }\end{array}$} & \multicolumn{2}{|c|}{ Coding Argumentasi } \\
\hline & & Laki-laki & Perempuan \\
\hline 1 & $\begin{array}{l}\text { Wilayah visi dan misi } \\
\text { (netral gender) }\end{array}$ & $\begin{array}{l}\text { - Tidak perlu kata gender } \\
\text { eksplisit } \\
\text { - Yang penting realitasnya } \\
\text { - Karena sudah setara }\end{array}$ & $\begin{array}{l}\text { - Tidakperlu kata gender } \\
\text { disebut }\end{array}$ \\
\hline $2,3,4$ & $\begin{array}{l}\text { Perangkat lunak } \\
\text { (software) kebijakan } \\
\text { (maqashidussyari'ah) }\end{array}$ & $\begin{array}{l}\text { - Perlu usulan untu policy PR } \\
\text { I } \\
\text { - Perlu tetapi tidak semua } \\
\text { - Relatif untuk body of } \\
\text { knowledge } \\
\text { - Kekhawatiran ekstrimisme } \\
\text { - Ilmu bebas kelamin }\end{array}$ & $\begin{array}{l}\text { - Pengembangan fak. } \\
\text { didasarkan } \\
\text { profesionalisme } \\
\text { akademik } \\
\text { Perlu dijelaskan } \\
\text { konsep setaradan adil } \\
\text { Pengembangan } \\
\text { keilmuan bebas } \\
\text { kelamin }\end{array}$ \\
\hline $5,6,7$ & $\begin{array}{l}\text { Instrumen Kebijakan } \\
\text { (produk tertulis } \\
\text { kebijakan) }\end{array}$ & $\begin{array}{l}\text { - Tidak Semua Tetapi } \\
\text { Khusus Saja } \\
\text { - Untuk Monitoring Perlu } \\
\text { - Tidak perlu yang penting } \\
\text { kegiatan, tambah masalah } \\
\text { - Yang penting kemajuan } \\
\text { adalah profesional. }\end{array}$ & $\begin{array}{l}\text { - Yang penting merujuk } \\
\text { pada profesionalisme } \\
\text { murni } \\
\text { - Perlu dipertimbangkan } \\
\text { - Tidak ada korelasi } \\
\text { signifikan }\end{array}$ \\
\hline 8,9 & $\begin{array}{l}\text { Penataan sistem } \\
\text { organisasi (petunjuk } \\
\text { teknis organisasi) }\end{array}$ & $\begin{array}{l}\text { - Bukan partisipasi jenis } \\
\text { kelamin tetapi } \\
\text { profesional,skill, ekspert } \\
\text { - Sebatas keyakinan }\end{array}$ & $\begin{array}{l}\text { Kompetensi adalah } \\
\text { kriteria utama }\end{array}$ \\
\hline $10,11,12$ & $\begin{array}{l}\text { Penataan SDM } \\
\text { (Pedoman } \\
\text { pengembangan) }\end{array}$ & $\begin{array}{l}\text { - Diakui ada hambatan tugas } \\
\text { tambahan prp non } \\
\text { formal,selain itu lihat juga }\end{array}$ & $\begin{array}{l}\text { Perlu, Tetapi Sesuai } \\
\text { Kodratnya } \\
\text { - Perempuan Harus }\end{array}$ \\
\hline
\end{tabular}




\begin{tabular}{|c|c|c|c|}
\hline & & $\begin{array}{l}\text { motivasinya } \\
\text { Memperhatikan } \\
\text { keseimbangan beban } \\
\text { formal-non formal (sensitif } \\
\text { gender) }\end{array}$ & $\begin{array}{l}\text { Profesional } \\
\text { Beban kerja prp non } \\
\text { formal mempengaruhi } \\
\text { kualitas SDM }\end{array}$ \\
\hline \multicolumn{2}{|c|}{ Kebutuhan praktis gender } & Laki-laki & Perempuan \\
\hline $13,14,15$ & $\begin{array}{l}\text { Eksplitasi tata kebijakan } \\
\text { fakultas berKKG } \\
\text { (obyektifikasi di tingkat } \\
\text { praktik) }\end{array}$ & $\begin{array}{l}\text { - Perlu dan penting untuk } \\
\text { aspek teknisnya } \\
\text { - Perlu garansi reproduksi } \\
\text { untuk kesetaraan } \\
\text { - Oleh karena itu harus ada } \\
\text { policy univ }\end{array}$ & $\begin{array}{l}\text { - Perlu, tetapi harus } \\
\text { profesional } \\
\text { - Perlu, tapi untuk } \\
\text { profesionalisme } \\
\text { keilmuan } \\
\text { - Sudah diatur negara }\end{array}$ \\
\hline $16,17,18,19$ & $\begin{array}{l}\text { Perangkat pendukung } \\
\text { tugas perempuan } \\
\text { (fasilitas yang } \\
\text { mempermudah } \\
\text { hambatan khusus prp) }\end{array}$ & $\begin{array}{l}\text { - Perlu pendukung agar } \\
\text { mempermudah tugas dan } \\
\text { kemauan berbagi } \\
\text { - Fasilitas proporsional/ tidak } \\
\text { ada lembur bagi perempuan } \\
\text { (jarang) } \\
\text { - Dibebankan keluarga dan } \\
\text { kantor, terlalu dalammasuk } \\
\text { ke wilayah kerja }\end{array}$ & $\begin{array}{l}\text { - Tidakperlu,karena } \\
\text { tidak ada kaitan dg } \\
\text { edukasi } \\
\text { - Dibedakan urusan } \\
\text { keluarga dan kantor } \\
\text { - Perlu ada fasilitas } \\
\text { tambahan,mis.tempat } \\
\text { menyusui atau } \\
\text { Penitipan Anak }\end{array}$ \\
\hline 20,21 & $\begin{array}{l}\text { Peraga sensitif gender } \\
\text { (simbol,kurikulum) }\end{array}$ & $\begin{array}{l}\text { - Penting sebagai } \\
\text { pemahaman } \\
\text { - Amat sulit diaplikasikan }\end{array}$ & - Tidak perlu dibedakan \\
\hline 22 & $\begin{array}{l}\text { Evaluasi kebijakan } \\
\text { (instrumen dan alat } \\
\text { ukur) }\end{array}$ & $\begin{array}{l}\text { - Ini tanggungan psg untuk } \\
\text { disosialisasikan }\end{array}$ & \\
\hline
\end{tabular}

Dari tabel dapat dideskripsiakn penjelasan sebagai berikut yaitu kebutuhan Strategis Gender yang meliputi ;

1. Pada indikator yang dikembangkan untuk item kebutuhan strategis gender,peneliti menemukan bahwa subyek memiliki pendapat yang mirip dan mempunyai cara pandang sendiri tentang kebutuhan strtegis gender terkait dengan visi dan misi fakultas masingmasing dan unit-unitnya. Baik laik-laki dan perempuan menginginkan visi dan misi tidakperlu secara eksplisit menyebutkan kata gender atau pemilahan jenis kelamin. Sebagian ada yang menginginkan kalau gender atau penyebutan jenis kelamin ada di realitasnya saja. 
2. Kebijakan akdemik yang sensitif gender sangat dibutuhkan jika disepakati atau menjadi bagian integral dari manajemen sensitif gender. Hal ini terlihat bahwa untuk aspek perangkat lunak kebijakan dan instrumen ebijakan berupa produk tertulis, subyek memberi argumentasi perlu akan tetapi tidak harus ekstrim dan menciptakan klan antara laki-laki dan perempuan. Namun mempertegas hal itu ada subyek yang memprioritaskan unsur profesionalisme sebagai kendalinya.

3. Indikator lain terkait dengan kebutuhan srategis gender tentang oeranan sistem organisasi yang dapat berupa petunjuk teknis manajemen organisasi dan penataan sumberdaya manusia seperti pedoman pengembangan SDM menunjukkan bagi kelompok laki-laki ada yang berkesimpulan tidak perlu membuat pedoman teknis tentang penyelesaian hambatanhambatan yang terkait dengan tugas formal dan non-formal terutama jika hal itu berhubungan dengan hambatan tugas reproduksi perempuan dan beban atau akses kesempatan mendapatkan peluang untuk maju. Walaupun pada kenyataannya ada argumentasi sebagian laki-laki menerima adanya petunjuk teknis sebagai hasil kebijakan dari komitmen beban ganda perempuan untuk menjadi pertimbangan kebijakan di fakultas. Argumentasi perempuan mengatakan lebih memprioritaskan profesionalisme. Namun ada yang menyebutkan bahwa profesionalisme profesionalisme terkait sumberdaya manusia juga dipengaruhi oleh beban kerja non-formal perempuan.

Sementara untuk kebutuhan praktis gender mencakup argumentasi sebagai berikut:

1. Kebutuhan praktis gender untuk mendukung implementasi kebutuhan strategis gender. Subyek pada aspek praktis memiliki memiliki argumentasi perlu dan penting untuk diterjemahkan ke aspek teknisnya akan tetapi harus didasarkan oleh kebutuhan profesional untuk keadilan dan kesetaraan gender. Seain itu harus didasari oleh kebijakan universitas untuk implementasinya. Argumentasi itu juga disampaikan oleh laki-laki dan perempuan. Antara laklaki dan peremnpuan cenderung menangkap kalau diperlukannya perangkat pendukung seperti fasilitas yang mempermudahkan perempuan ada yang kurang memadahi karena tidak ada kaitannya dengan profesionalisme dan harus dibedakan antara urusan kantor dan rumah tangga. Namun ada subyek yang menganggap perlu menyediakan fasilitas privat yang dibutuhkan bagi perempuan, contohnya tempat untuk menyusui atau penitipan anak.

2. sedangkan untuk peraga gender meliputi simbol-simbol atau kurikulum, ada pendapat hal ini perlu karena untuk pemahaman namun ada anggapan bahwa hal itu sulit diaplikasikan. 
Subyek perempuan berpendapat bahwa perlu ada pembedaan jenis kelamin baik pada wilayah simbol atau kurikulum.

3. Untuk evaluasi kebijakan, subyek memberi masukan alangkah baiknya mengenai evaluasi itu adalah wewenang Pusat Studi Gender untuk giat melakukan sosialisasi mengenai bagaimana instrumen dan alat ukur evaluasi menjadi bagian integral dalam penyelenggaraan proses belajar mengajar.

\section{E. Kesimpulan dan Saran}

Hasil penelitian tersebut hendaknya menjadi kajian lebih lanjut pada implementasi pengarusutamaan gender sebagai studi permulaan menuju proses penguatan kesetaraan dan keadilan gender. melalui temuan penelitian ini peneliti menyampaikan kepada rekomendasi berupa saran-saran bagi kegiatan atau penelitian selanjutnya yang anatara lain:

1. Bagi penelitian selanjutnya. Perlu membakukan instrumen tentang pengarusutamaan gender yang dapat digunakan oleh praktisi gender atau sebagai alat pengembangan pengarusutamaan gender di pendidikan tinggi.

2. Bagi pengambil kebijakan. Bahwa tujuan pembangunan di Indonesia saat ini harus melibatkan pengarusutamaan gender dan hasilpenelitian ini perubahan persepsi gender sangat dimungkinkan karena persepsi para pejabat di tingkat fakultas cenderung tidak absolut menolak gender menjadi bagian integral dariprogram pengembangan fakultas dan optimalisasi sumbardaya manusia.

3. Bagi Pusat Studi Gender. Penelitian menjadi pintu masuk melihat peta permasalahan yang menghambat bagi implementasi pengarusutamaan gender dan perlu menyusun kegiatan sosialisasi yang lebih intens di seluruh elemen Uinversitas Islam Negeri (UIN) Malang. 


\section{DAFTAR PUSTAKA}

Ahimsa Putra, Heddy Sri, Enam Pemaknaan Gender, Makalah, 2001.

Antrobus, Peggy, The Global Women Movement, Bangladesh: The university Press, 2004.

Dőge,Peter, Theoretical Implications of Gender Mainstreaming. Overhead Slides.www.IAIZ.de. Institut fǘr anwendungsorientierte, Innovations-und Zukunftsforschung $\boldsymbol{e} . \boldsymbol{V} .2002$.

European Women and Sport, 2002. A New Strategy: Gender Mainstreaming, Berlin: Teresa Rees, 2002.

Fakih, Mansour, Analisis Gender dan Transformasi Sosial, Yogyakarta: Pustaka Pelajar.

Macdonald, Mandy, dkk, Gender dan Perubahan Organisasi, Menjembatani Kesenjangan antara Kebijakan dan Praktek, Terj. Omi Intan Naomi, Yogyakarta: INSIST, 1999.

Mosse, Julia Cleves, Gender dan Pembangunan, Yogyakarta: Pustaka Pelajar, 1996

Muhadjir, Noeng, Metode Penelitian Kualitatif, Yogyakarta: Rake sarasin, 2002

Saptari, Ratna dan Brigitte Halzaner, Perempuan Kerja dan Perubahan Sosial, Jakarta: Pustaka Utama Grafitti, 1997

Subhan, Zaitunah, Tafsir Kebencian, Studi Bias Gender dalam Tafsir Quran, Yogyakarta: Lkis, 1999 
